\title{
The Effect of Crisis Processing Capacity on Brand Crisis Reparability
}

\author{
Yi Xiao, Qing Li, Haiying Wei \\ School of Business Administration, Jinan University, Guangzhou, China \\ Email:yi_yi19@hotmail.com
}

Received 11 August 2014; revised 8 September 2014; accepted 2 October 2014

Copyright @ 2014 by authors and Scientific Research Publishing Inc.

This work is licensed under the Creative Commons Attribution International License (CC BY). http://creativecommons.org/licenses/by/4.0/

\section{(c) (i) Open Access}

\begin{abstract}
With the constantly changing surroundings and highly developed technology, brand crisis accordingly shows the increasing trend, which took a lot of companies by surprise and made them especially hard-hit. In brand crisis companies usually adopt an apology, compensation, denied and silent strategy to cope with consumers, hoping to be able to get consumers to forgive and repair the damaged brand relationship. This work firstly put forward a concept "reparability of brand crisis", which should be defined to judge how an enterprise could be repaired from a brand crisis, and selected crisis processing capacity index to build up impact model about how enterprise's crisis processing capacity affected the degree of brand crisis reparability.
\end{abstract}

\section{Keywords}

\section{Brand Crisis, Enterprise Processing Capacity, Reparability}

\section{Introduction}

Nowadays it's very common that the domestic and foreign enterprises go through Brand Crisis. With the brand crises, companies would inevitably suffer huge reputation and economic losses, and some companies go through a series of remedial measures to achieve the enterprise's recovery while some companies never got over the shock. Therefore, we found that some crisis were able to be repaired while some crisis were not able to be repaired. At present researches study the crisis in terms of corporation and have high value in practice, however, they are all based on the hypothesis that brand crisis is recoverable, and at same time, put little emphasis on the recoverable brand crisis mechanism. Therefore, there are few researches about whether the crisis can be recovered. So at first, this work put forward the concept of brand crisis reparability and then made a discussion of the impact mechanism between enterprise processing capabilities of the crisis and the brand crisis reparability. 


\section{Literature Review}

\subsection{Brand Crisis}

Brand crisis can seriously hurt a firm's performance (e.g., Chen, Ganesan, and Liu 2009).The definition of brand crisis is not unified, scholars use a variety of different appellation, including negative marketing events, negative exposure, brand scandal, negative brand exposure events, etc. to do research of this topic. Ming-Yang Yu think brand crisis is due to the organization of internal and external incidents and cause the damage to the brand image and brand value, making the organization in difficult and dangerous situation [1]. Dawar and Lei were the first scholars who defined what is brand crisis, they defined brand crisis as a widely spread incident that is false or the important proposition about the brand hasn't been confirmed, it will cause serious damage to the brand [2]. Wei Haiying on the basis of predecessors' research, in the perspective of relationship, defined brand crisis as a serious distorted brand relationship that led by the widely spread negative brand incidents, and even temporary or permanent condition. The research of product damage crisis is always the important territory for many scholars. And there receives a comparably mature conclusion on crisis classification, causes, effect and strategies [3].

\subsection{Discussion of Reparability}

The definition of reparability earliest appeared in engineering science, clinical medicine, information technology, constructional engineering and so on.

Although engineering and clinical medicine studied reparability a long history, but there was seldom scholar made a definition of "reparability", let alone formed a subject within the concept of unified recognition. In engineering, Wei-Liang Jin, Ping-Hua Zhu for the durability of concrete structures proposed that reparability is under the concrete structure in the foreseeable internal working environment and material factors, the damage from atmospheric effects due to chemical erosion and other factors leading to the deterioration can be repaired by physical or chemical way [4]. Research on the parts of aeronautics to determine whether the parts can be repaired is analysis to focus on the possibility that scraped hot parts resulting from certain damage could be repaired to recover its feasibility.

So far, many scholars in different fields of science have studied on the definition of "repairable" and how to assess "repairable" degree. These researches suppose that the reparability of brand crisis need to assess the objective damage of the crisis and the subjective ability, and thus get the possibility that the brand crisis could be repaired. In conclusion, the discussion of "repairable" starting from the damage situation, combined with the resources in repair action, need and the cost of repair action and how much can the enterprise fulfill. In this work, from the perspective of relations, in order to conduct a comprehensive brand crisis repairable and effective assessment, we propose corporate capacity indicators to characterize the capacity of the enterprises regain consumer satisfaction and repair the relationship between consumer and brand.

\section{Crisis Processing Capabilities Overview and Dimensions Selected}

\subsection{Crisis Processing Capabilities Overview}

From the perspective of cognitive psychology, the essence of the brand crisis lies in the distrust attitude and behavior of consumer toward to enterprises and their products. Therefore, under the brand crisis situations, establishing a special crisis management group, doing effective media communication and showing immediately response are quite important measures of enterprise crisis management, because this measures and crisis response speed show concern for consumers, which are helpful to maintain consumers' positive attitude towards crisis enterprise and save the buying behavior of consumers. Therefore, crisis processing capabilities should include the ability to manage a combination of events and the impact of crisis, thereby affecting consumer brand integrated response after the crisis in the cognitive, emotional and behavioral aspects. Consumer is the source of repairable brand crisis, consumer psychological reactions represents the level of brand crisis reparability. In summary, the cognitive processes of crisis situations have important effect to crisis reparability level.

\subsection{Crisis Processing Capabilities Dimensions Selected}

Based on interviews with businesses and consumers, crisis management should be divided into two aspects: event management and impact management. When a brand crisis, companies need to rapidly investigate of in- 
jury reasons for the crisis, the situation of the groups involved in and quickly come up with effective coping strategies and measures.

The formation and evolution of the brand crisis is dependent on the media and the social public to the brand of the negative public reporting, circulating and express opinions. Therefore, enterprises must adopt effective impact management behavior. Based on in-depth interviews, companies believe that the crisis spread after the incident in a timely manner to contain and reduce the expansion of the scope of the event, the event is no longer causing public concern can be defined as the crisis is over.

\section{Building up Model of Enterprise Crisis Processing Capability's Effect on Brand Crisis Reparability}

\subsection{Theoretical Model about How Enterprise Crisis Processing Capabilities Affects Brand Crisis Reparability}

Enterprise crisis processing capabilities based on enterprise as the main controller during a crisis refers to capabilities in order to achieve the worsening crisis management actions to reduce the harm of the crisis, or turning the crisis into opportunities for the development. Through interviews with a number of consumer and posttreatment coding found in the crisis management process, what consumers need are companies quickly respond to consumer demands, a positive response to the facts and make a note subsequent processing. To meet the demands of consumers, enterprises need to establish stabilizing brand management capabilities and the corresponding basic management capabilities.

Founder, Ming-Hua Jiang summarizes the product harm will have negative impact including lower consumer loyalty and consumers repurchase [5], Michael K. Brady proposed the brand assets can be effectively offset the effect of service failure, high brand equity brand will get higher customer satisfaction and repurchase intention [6]. In addition, studies show that corporate social responsibility behavior will improve consumer evaluation of the enterprise. Research of Klein and Dawar suggests that corporate social responsibility has a directly and strongly effect on consumers' crisis attribution, it can reduce the condemn level when a crisis event occurs, in short, the corporate social responsibility can play an effective role of buffer [7].

From literature research and interview results, combining with the characteristics of brand crisis, select brand crisis early-warning management team, brand-based management, brand equity and corporate social responsibility as indicators, construct theoretical model about how enterprise crisis processing capabilities effect brand crisis reparability (Figure 1).

\subsection{Theoretical Model Analysis}

After the brand crisis, there is quite a short time allowing enterprises to react, what's more, enterprises have to make a quick and accurate response to meet the needs of consumers and the public, it asks for quite high brand management capability.

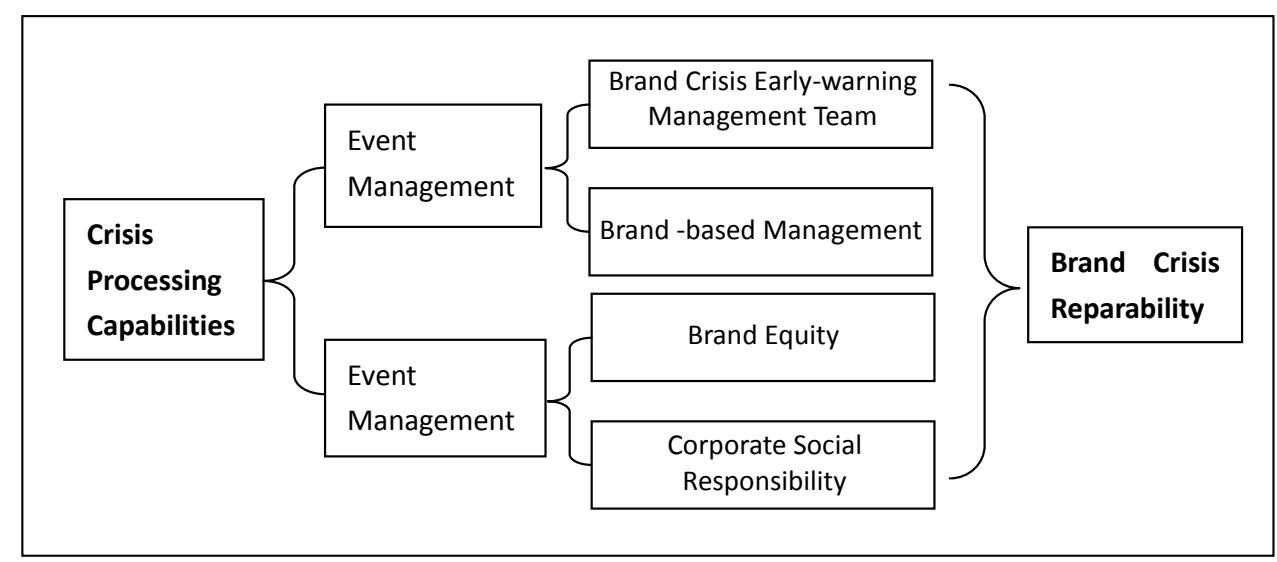

Figure 1. Theoretical model of enterprise crisis processing capability’s effect on brand crisis reparability. 
This study is based on processing the brand crisis, and therefore proposed definition of brand management from a crisis management perspective: that in the brand's life cycle management of enterprises to establish brand awareness of a daily crisis management process, designed to avoid loss of corporate brand value, and in the event of a crisis try to reduce the loss as much as possible through taking a series of management actions. Specific management behavior include: 1) establish a brand crisis early-warning management team, members should be organized by professionals and managers have decision-making power in the form; 2) build a brand self checking system, the brand management on a regular basis for inspection, analysis and correction, find out the defect part; 3) establish a highly sensitive, accurate and timely forecast system of crisis, companies can regularly have brand test and inspection, clearly predict all kinds of brand status; 4) classify the brand awareness into the enterprise culture management, brand crisis management education and training to employees are important link in enterprise management, when brand crisis occurs employees can effectively cooperate organization crisis.

Brand-based management level indicators include financial support and human resources configuration two secondary indexes. Financial support includes two aspects: First, resource availability rate expressed as a real number to and should go to the resource (or value) ratio; Second, the effectiveness of the use of resources, in order to effectively put the ratio of the total investment. Human resource configuration includes two aspects, one is quantitative, it's a ratio of people belong to operation management and enterprise brand compare to the total number of enterprise; Second, qualitative aspects, brand operation management department personnel's quality, especially the brand management skill and the degree of the brand management professional training.

Different from most of the scholars from the perspective of consumers measuring the brand equity, this study adopts the enterprise level to measure brand equity and characterize the enterprise crisis management ability level. Dawar and Pillutla's research suggests that brand equity can weaken the impact of the brand crisis, proposed as peripheral cue brand equity has become an important basis to affect the attitude of consumers to the brand, the higher brand equity, the smaller negative impact of the crisis; Sloot, Verhoef and Franses targeted directly to brand equity study found that when a crisis occurs product damage, high consumer loyalty to the brand's high asset. Wang Haizhong, Yu Chunling and Zhao Ping verify the corporate level brand equity in 2006 reflect the psychological level of consumer brand equity [8]. Therefore, this level indicator of brand equity includes market share, brand market sales, the profit margin three secondary indicators [9].

So far a large number of domestic and international studies have shown that corporate social responsibility has a positive impact on consumers, mainly in consumer corporate identity, evaluation and other aspects of consumers' willingness to buy. Zu-Cheng Zhou, Yi-Jie Zhang corporate social responsibility will be divided by two to the level, the experimental study found that corporate social responsibility has a positive influence on consumer purchase intention [10]. We believe that corporate social responsibility under the brand crisis situations can certainly dilute the damage extent in consumer the emotions, attitudes and behavior. This study follows the Yan-Feng Zhou's result to take the donor charity, environmental protection and well-treat employees three dimensions of corporate social responsibility to refine measurements.

\section{Conclusion}

In order to achieve the desired business crisis repairing effect, prompting public and consumer awareness and evaluation of enterprise transformation, companies should keep a sense of crisis in mind, improving crisis daily management ability. In addition, crisis warming system and brand-based management construction work are very necessary, as well as the establishment of high brand equity and high standards of corporate social responsibility image. Once brand crisis broke out, it is great helpful to minimize the negative impact of the crisis including consumer negative cognition.

\section{Acknowledgements}

This paper is financially supported by the projects: The Study on the Reparability of Brand Crisis and the Influencing Factors (ID: 2012JDXM_0010) and Impacts of Corporate Interaction Ritual on The Brand Crisis Repairing Effect from Relations Conflict Perspective (ID: 71372169).

\section{References}

[1] Yu, M.Y. (2008) Brand Crisis Management. Wuhan University Press, Wuhan, 208-212. 
[2] Dawar, N. and Lei, J. (2009) Brand Crises: The Roles of Brand Familiarity and Crisis Relevance in Determining the Impact on Brand Evaluations. Journal of Business Research, 62, 509-516. http://dx.doi.org/10.1016/j.jbusres.2008.02.001

[3] Wei, H.Y. (2011) Brand Crisis Management. Jinan University Press, Guangzhou, 29-32.

[4] Jin, W.L .and Zhu, P.H. (2005) Restorability Class Partition for Durability of Concrete Structure. Journal of Architecture and Civil Engineering, 22, 64-70.

[5] Fang, Z., Jiang, M.H., Yang, Y. and Li, W. (2010) Research on the Effect of Coping Strategy for Product Harm Crisis. Ruan Ke Хue, 143, 73-77.

[6] Michael, K., Brady, Joseph Cronin Jr., J., Fox, G.L. and Roehm, M.L. (2008) Strategies to Offset Performance Failures: The Role of Brand Equity. Journal of Retailing, 84, 151-164. http://dx.doi.org/10.1016/j.jretai.2008.04.002

[7] Klein, J. and Dawar, N. (2004) Corporate Social Responsibility and Consumers' Attributions and Brand Evaluations in a Product-Harm Crisis. International Journal of Research in Marketing, 21, 203-217. http://dx.doi.org/10.1016/j.ijresmar.2003.12.003

[8] Wang, H.Z., Yu, C.L. and Zhao, P. (2006) Relationship between Consumer Mode of Brand Equity and Product Market Output Mode. Management World, 1, 106-119.

[9] Zhou, Y.F., Luo, W.E. and Xiao, W.J. (2007) Corporate Social Responsibility Behavior and Consumer ResponsesThe Moderator Effects of Consumer Personal Characteristic and Price Signal. China Industrial Economy, 228, $23-28$.

[10] Zhou, Z.C. and Zhang, Y.J. (2007) Empirical Study on Relative Level of Corporate Social Responsibility in an Industry and Consumers' Purchase Intention. China Industrial Economy, 234, 111-118. 
Scientific Research Publishing (SCIRP) is one of the largest Open Access journal publishers. It is currently publishing more than 200 open access, online, peer-reviewed journals covering a wide range of academic disciplines. SCIRP serves the worldwide academic communities and contributes to the progress and application of science with its publication.

Other selected journals from SCIRP are listed as below. Submit your manuscript to us via either submit@scirp.org or Online Submission Portal.

